\title{
Formulasi Sediaan Deodoran dalam Bentuk Krim Menggunakan Kombinasi Aluminium Sulfat dan Minyak Kayu Cendana
}

\section{Formulation of Deodorant Cream Dosage Form Using a Combination of Aluminum Sulfate and Sandalwood Oil}

\author{
Willi Wahyu Timur, Fadzil Latifah \\ Prodi Farmasi Universitas Islam Sultan Agung Semarang, \\ JL. Kaligawe Raya Km. 4, Semarang, Indonesia \\ Sur-el : willi_wahyu@unissula.ac.id
}

\begin{abstract}
ABSTRAK
Aluminium sulfat dapat digunakan untuk penyumbatan saluran keringat dengan cara membentuk endapan protein keringat, membentuk endapan keratin epidermis, membentuk infiltrat dinding saluran keringat. Sediaan deodoran perlu dikembangkan karena bau badan menimbulkan masalah yang berefek fatal terhadap penampilan dan pergaulan seseorang. Penelitian deodoran krim dibuat dari kombinasi aluminium sulfat dan minyak atsiri kayu cendana (MAKC). Penelitian ini bertujuan untuk melihat sifat fisik, uji iritasi dan kenyamanan dari sediaan krim Kombinasi Aluminium Sulfat dan MAKC. Penelitian ini diawali dengan formulasi krim dibuat dari kombinasi aluminium sulfat dan MAKC dengan konsentrasi 4\%. Krim dievaluasi sifat fisik dengan parameter daya sebar, daya lekat, viskositas dan $\mathrm{pH}$. Selain itu juga di evaluasi daya iritasi terhadap kulit menggunakan hewan uji kelinci albino serta kenyamanan penggunaan. Data yang diperoleh dianalisis dengan statistik dengan taraf kepercayaan $95 \%$ untuk mengetahui adanya perbedaan yang signifikan antar kelompok perlakuan. Hasil analisis menunjukkan bahwa sifat fisik dari respon ( $\mathrm{pH}$, daya sebar, daya lekat, viskositas). Hasil $\mathrm{pH}$ memiliki nilai $\mathrm{p}<0,05$. Hasil daya lekat memiliki nilai $p<0,05$ Hasil daya sebar memiliki nilai $p<0,05$ Hasil nilai viskositas $p>0,05$. Krim dengan kombinasi bahan tersebut tidak mengiritasi pada kulit kelinci. Hasil aseptabilitas diperoleh sediaan yang nyaman digunakan.
\end{abstract}

Kata kunci : deodoran, aluminium sulfat, kayu cendana, uji iritasi, sifat fisik

\begin{abstract}
Aluminum sulfate can be used for sweat duct blockage by forming sweat protein sediment, forming epidermis keratin sediment, forming sweat duct wall infiltrate. Deodorant preparation needs to be developed because body odor causes problems with fatal effect on someone's appearance and interaction. The study aimed to see the physical characteristics, irritation test, and comfort of Aluminum Sulfate and Sandalwood Essential Oil combination cream preparation. The study was started with formulation of cream made of combination of aluminum sulfate and sandalwood essential oil with concentration of 4\%. The physical characteristics of the cream was evaluated with parameters of spreading power, stickiness, viscosity, and $\mathrm{pH}$. Besides that, the study also evaluated the irritability on skin using albino rabbit as test animal and comfort of use. The date obtained were analyzed using statistics with confidence level of $95 \%$ to investigate any significant difference between treatment groups. The result of analysis showed the physical characteristics of response ( $\mathrm{pH}$, spreading power, stickiness, and viscosity). The result of pH had value of $p<0.05$. The result of stickiness had value of $p<0.05$. The result of spreading power had value of $p<$ 0.05 . The result of viscosity had value of $p>0.05$. The cream with combination of the materials did not irritate the rabbit skin. The result of acceptability obtained preparation that was comfortable to use.
\end{abstract}

Keywords: deodorant, aluminum sulfate, sandalwood, irritation test, physical test

\section{PENDAHULUAN}

Bau badan adalah salah satu masalah kehidupan dalam sehari hari. Bau badan yang tidak sedap tersebut disebabkan oleh aktivitas bakteri Staphylococcus epidermidis (Wen, 2009). Masalah yang ditimbulkan tersebut 
berefek fatal terhadap penampilan dan pergaulan sesorang.

Terdapat dua jenis kelenjar penghasil keringat yaitu kelenjar apokrin dan kelenjar ekrin. Kelenjar apokrin pada ketiak mengandung sejumlah protein dan zat gula yang nantinya diuraikan oleh bakteri sehingga menghasilkan bau seperti amonia. Selain itu, kelenjar keringat di ketiak merupakan penghasil air yang cukup besar dan terdapat pula bulu-bulu ketiak yang semakin mempermudah dan memperluas aktivitas bakteri yang menghasilkan bau tidak sedap tersebut (Djuanda, 2008). Oleh karena itu, banyak masyarakat yang menggunakan deodoran untuk menghilangkan bau tersebut.

Aluminium klorohidrat dan aluminium klorida pada umumnya digunakan sebagai zat aktif untuk sediaan antiperspiran karena mempunyai sifat astringen dan antibakteri dan mempunyai $\mathrm{pH} 4$ yang tidak menyebabkan iritasi dan tidak merusak jaringan kulit (POM, 1985) (Butler, 2000).

Pemanfaatan Santalum oil sebagai deodorant dapat diformulasikan dalam bentuk sediaan krim. Bentuk yang digunakan ini mudah menyebar merata, sangat praktis, selain itu juga mudah di bersihkan atau dicuci dan cara kerjanya berlangsung dijaringan setempat (Widodo, 2013). Deodoran merupakan sediaan kosmetik yang dapat menghentikan pengeluaran keringat yang berlebih dan menghambat aktivitas bakteri untuk menguraikan keringat sehingga menghasilkan bau kurang sedap (Rahayu, et al., 2009).

Salah satu parameter penting untuk diperhatikan dalam sediaan krim deodoran adalah apakah produk yang dihasilkan menimbulkan iritasi terhadap kulit atau tidak dan sifat fisik sediaan. Iritasi pada kulit dapat disebabkan oleh beragam faktor diantaranya lama pemberian, luas area pemberian, tingkat penetrasi dan ketoksikan dari bahan yang diaplikasikan (Fatmawaty, et al., 2016). Iritasi dapat terjadi setelah beberapa waktu dari pengaplikasian sediaan, dengan gejala seperti kulit mengering, terasa nyeri, mengalami perdarahan, dan pecah-pecah. Eritema atau kemerahan yang terjadi pada kulit yang iritasi disebabkan karena terjadinya dilatasi pembuluh darah pada daerah yang teriritasi tersebut, selain iritasi udema juga dapat terjadi pada kulit yang teriritasi, yang dapat diamati dengan terjadinya perbesaran plasma yang membeku pada daerah yang terluka, dan dipercepat dengan adanya jaringan fibrosa yang menutupi daerah tersebut (Irsan, et al., 2013). Optimasi perlu dilakukan untuk mendapatkan sediaan dengan efek terbaik.

Optimasi sediaan topikal dilakukan dengan menentukan batasan (goal) kriteria respon yang dikehendaki dengan range yang memungkinkan untuk dicapai. Strategi dilakukan melalui optimasi yang terkonsep, baik menggunakan metode salah satunya simplex lattice design (SLD). Formula yang paling optimal adalah formula dengan nilai desirability maksimum. Nilai desirability 
merupakan nilai fungsi untuk tujuan optimasi yang menunjukkan kemampuan program untuk memenuhi keinginan berdasarkan kriteria yang ditetapkan pada produk akhir. Nilai desirability yang semakin mendekati nilai 1,0 menunjukkan kemampuan program untuk menghasilkan produk yang dikehendaki semakin sempurna (Ramadhani, et al., 2017). Optimasi sediaan krim kombinasi aluminium sulfat dan MAKC dan evaluasi sifat fisik, daya iritasi, akseptabilitas dari krim perlu dilakukan untuk dapat menghasilkan sediaan farmasi topikal dalam bentuk krim yang efektif sebagai anti deodoran, tidak mengiritasi kulit, nyaman dipakai dan memiliki sifat fisik baik.

\section{METODE PENELITIAN}

\section{Formulasi deodoran krim dibuat dari kombinasi aluminium sulfat dan minyak atsiri kayu cendana}

Formulasi deodoran krim dibuat dari kombinasi aluminium sulfat dan minyak atsiri kayu cendana dibuat dengan cara memisahkan bahan-bahan yang digunakan menjadi dua bagian, yaitu bahan yang larut fase minyak dan bahan yang larut fase air. Kemudian panaskan masing-masing kedua fase tersebut. Bahan-bahan yang larut minyak yaitu vaselin album, setil alkohol dimasukkan ke dalam cawan porselen untuk dipanaskan dan diaduk hingga homogen. Pada fase air yaitu natrium lauril sulfat, tawas, propilenglikol, metilparaben, propilparaben, aquadest juga dipanaskan seperti fase minyak.
Fase minyak dan fase air dipanaskan dan diaduk pada suhu $70^{\circ} \mathrm{C}$ secara terpisah dari fase minyak hingga homogen. Setelah kedua fase masing-masing telah homogen, dilakukan pencampuran antara fase minyak dan fase air hingga tercampur merata. Minyak atsiri kayu cendana akhir waktu pencampuran karena minyak atsiri mudah menguap maka ditambahkan setelah sistem emulsi terbentuk (Billany, 2002).

\section{Evaluasi Sifat Fisik deodoran krim dibuat dari kombinasi aluminium sulfat dan minyak atsiri kayu cendana}

\section{Uji Daya Sebar}

Sebanyak 0,5 gr krim diletakkan diatas kaca bulat yang berdiameter $15 \mathrm{~cm}$, kaca lainnya diletakkan diatasnya dan dibiarkan selama 1 menit. Diameter sebar salep diukur. Setelahnya, di atas krim ditambahkan 100 gr beban tambahan dan didiamkan selama 1 menit lalu diukur diameter yang konstan (Astuti, et al., 2010).

\section{Uji Daya Lekat}

Sebanyak 0,5 g krim diletakkan di atas gelas obyek yang telah ditentukan luasnya. Obyek gelas yang lain diletakkan di atas krim tersebut. Di atas ditambahkan beban $1 \mathrm{~kg}$ selama 5 menit. Obyek gelas dipasang pada alat tes. Beban seberat $80 \mathrm{~g}$ dilepas. Waktu hingga kedua gelas obyek tersebut terlepas dicatat. Prosedur diulangi sebanyak 5 kali untuk masing-masing tipe krim (Rahmawati, et al., 2010) 


\section{Uji $p H$}

Sebanyak 0,5 g salep diencerkan dengan 5 $\mathrm{ml}$ aquades, kemudian dicek $\mathrm{pH}$ larutannya (Naibaho, et al., 2013).

\section{Uji viskositas}

Krim diamati tingkat kekentalannya dari masing-masing konsentrasi ekstrak dengan menggunakan viscometer Brook field LV. Sediaan dimasukkan ke dalam cup, kemudian dipasang spindle ukuran 4 dan rotor dijalankan dengan kecepatan $30 \mathrm{rpm}$. Angka yang diperoleh kemudian dikalikan dengan faktor koreksi 200. Viskositasnya (cp) adalah angka hasil pengukuran $\mathrm{x}$ faktor konversi (Rahayu, et al., 2009).

\section{Evaluasi daya iritasi deodoran krim dibuat dari kombinasi aluminium sulfat dan minyak atsiri kayu cendana}

Uji iritasi menggunakan hewan uji kelinci sebanyak 4 ekor kelinci albino berumur ratarata 6 bulan. Dalam penelitian ini uji iritasi menggunakan metode yang digunakan Remington, yaitu pach test atau uji sampel. Rambut kelinci dicukur pada bagian punggungnya sampai bersih. Untuk menghilangkan bulu halus digunakan veed sebagai perontok bulu-bulu halus. Pencukuran dilakukan secara hati-hati agar tidak melukai punggung kelinci. Punggung kelinci dibagi menjadi 4 bagian yang berbentuk bujur sangkar. Kemudian sediaan krim dengan dari kombinasi aluminium sulfat dan MAKC diaplikasikan pada kulit. Evaluasi dilakukan selama 72 jam untuk melihat perubahanperubahan yang terjadi seperti eritema dimana kulit menjadi kemerahan dan timbul bercakbercak. Untuk penentuan skor berdasarkan skor pada uji sampel sebagai berikut; 0: tidak ada reaksi, 1: eritema ringan (warna kulit agak merah), 2: eritema sedang (warna kulit merah dan timbul bintik-bintik merah), 3: eritema kuat (warna kulit sangat merah dan bintik merah lebih banyak).

\section{Uji Akseptabilitas}

Responden harus keadaan sehat serta tidak memiliki penyakit kulit. Sediaan deodoran krim digunakan dengan cara mengoleskan pada kulit ketiak responden, kemudian didiamkan selama 1 menit (Saryanti \& Izzatun, 2017).

\section{HASIL DAN PEMBAHASAN}

Pemilihan krim pada penelitian ini dikarenakan mudah menyebar dan merata sehingga dapat memberikan kenyamanan saat digunakan. Evaluasi untuk melihat kualitas fisik pada krim berupa daya sebar, daya lekat, $\mathrm{pH}$ dan viskositas dilakukan untuk mengetahui kualitas sediaan fisik krim.

\section{Optimasi Sifat dan Kimia Formula SLD dan Penentuan Formula Optimum}

Berikut adalah formula 1 sampai 8 diuji sifat fisik. Data menampilkan daya sebar, daya lekat, $\mathrm{pH}$, dan viskositas. Hasil pengujian sifat fisik dapat dilihat pada tabel 2 . 
Tabel 1. Formulasi sediaan deodoran krim dibuat dari kombinasi aluminium sulfat dan minyak atsiri kayu cendana

\begin{tabular}{lrrrrrrrr}
\hline \multicolumn{1}{c}{ Bahan } & \multicolumn{1}{c}{ Komposisi } \\
\cline { 2 - 10 } & \multicolumn{1}{c}{ F1 } & F2 & F3 & F4 & F5 & F6 & F7 & F8 \\
\hline Minyak asiri kayu & 4 & 4 & 4 & 4 & 4 & 4 & 4 & 4 \\
Tawas & 15 & 15 & 15 & 15 & 15 & 15 & 15 & 15 \\
Vaselin album & 10 & 30 & 20 & 25 & 15 & 20 & 30 & 10 \\
Na lauril sulfat & 2,5 & 0,5 & 1,5 & 1 & 2 & 1,5 & 0,5 & 2,5 \\
Propilenglikol & 18 & 18 & 18 & 18 & 18 & 18 & 18 & 18 \\
Setil alcohol & 4 & 4 & 4 & 4 & 4 & 4 & 4 & 4 \\
Metil paraben & 0,02 & 0,02 & 0,02 & 0,02 & 0,02 & 0,02 & 0,02 & 0,02 \\
Profil paraben & 0,18 & 0,18 & 0,18 & 0,18 & 0,18 & 0,18 & 0,18 & 0,18 \\
Aquadest & 46,3 & 28,3 & 37,3 & 32,8 & 41,8 & 37,3 & 28,3 & 46,3 \\
Total & 100 & 100 & 100 & 100 & 100 & 100 & 100 & 100 \\
\hline
\end{tabular}

Keterangan: $\mathrm{F}=$ Formula
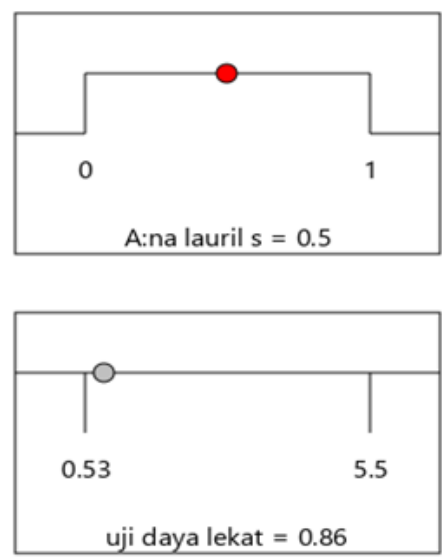

Desirability $=0,812$

Solution 1 out of 21

Gambar 1. Uji sifat fisik sediaan deodoran Krim minyak atsiri kayu cendana dianalisa menggunakan software design expert versi 11.

Data yang diperoleh dari uji sifat fisik sediaan krim deodoran dianalisa menggunakan software design expert versi 11 (trial). Hasil optimasi disajikan pada gambar 1.

Gambar tersebut menunjukkan nilai desirability maksimum yang didapatkan pada dari ke-8 formula adalah 0,812. Dari 21 solution yang disajikan, dipilih perbandingan komposisi na. lauril sulfat dan vaselin sebesar SLS 1,5 dan vaselin $20 \%$.

Hasil optimasi formula sediaan deodoran krim kombinasi alumunium sulfat dan MAKC menunjukkan nilai desirability tertinggi (mendekati nilai 1) dari 21 formula yang disarankan oleh software design expert sebesar 0,812 dengan perbandingan

Tabel 2. Variasi formula sediaan krim

\begin{tabular}{ccccc}
\hline $\begin{array}{c}\text { For- } \\
\text { mula }\end{array}$ & $\begin{array}{c}\text { Daya } \\
\text { sebar }\end{array}$ & $\begin{array}{c}\text { Daya } \\
\text { lekat }\end{array}$ & $\mathrm{pH}$ & $\begin{array}{c}\text { Visko- } \\
\text { sitas }\end{array}$ \\
\hline F1 & 4.725 & 0.79 & 4.1 & 2300 \\
F2 & 3.3 & 0.66 & 4.1 & 1380 \\
F3 & 3.425 & 1.19 & 4 & 3790 \\
F4 & 3.625 & 5.5 & 4 & 4900 \\
F5 & 5.525 & 1.31 & 4.1 & 4700 \\
F6 & 5.895 & 0.53 & 4.1 & 2172 \\
F7 & 3.375 & 1 & 3.9 & 3184 \\
F8 & 4.05 & 2.1 & 4 & 2374 \\
\hline
\end{tabular}


Tabel 3. Formula optimum deodoran krim dibuat dari kombinasi aluminium sulfat dan MAKC

\begin{tabular}{lc}
\hline Bahan & Konsentrasi \\
\hline MAKC & 4 \\
Tawas & 15 \\
Vaselin album & 20 \\
Na lauril sulfat & 1,5 \\
Propilenglikol & 18 \\
Setil alcohol & 4 \\
Metil paraben & 0,02 \\
Profil paraben & 0,18 \\
Aquadest & 37,3 \\
\hline
\end{tabular}

konsentrasi natrium lauril sulfat 1,5 dan vaselin album $20 \%$ Nilai desirability semakin mendekati nilai 1 menunjukkan bahwa program tersebut mampu menghasilkan produk yang dikehendaki semakin sempurna. Tujuan optimasi bukanlah memperoleh nilai desirability 1, tetapi mencari konsentrasi terbaik yang mempertemukan semua fungsi dan tujuan (Raissi dan Farzani, 2009).

\section{Pengujian Sifat Fisik Formula Optimum} krim
Uji daya sebar pada krim dilakukan untuk melihat kemampuan menyebar pada kulit. Hasil daya sebar Krim pada penelitian ini dapat dilihat pada gambar 3. Syarat daya sebar untuk sediaan topikal adalah $5-7 \mathrm{~cm}^{2}$ (Garg, et al., 2002), pada penelitian ini daya sebar yang diperoleh belum memenuhi syarat yang di tentukan. Pada formula optimum didapatkan daya sebar $4,01 \mathrm{~cm}^{2}$ dan kontrol positif $4,53 \mathrm{~cm}^{2}$. Pada pengujian statistik data tidak terdistribusi normal dan homogen dengan uji Mann whitney $\mathrm{p}=0,008$, jadi $\mathrm{p}<0,5$. Hal ini berarti ada perbedaan signifikan antara formula optimum dengan kontrol positif.

Untuk melihat kemampuan krim dalam melekat pada kulit perlu diuji daya lekat. Hasil uji daya lekat pada penelitian ini dapat dilihat pada gambar 4. Syarat untuk sediaan topikal tidak kurang dari 4 detik (Ulaen, et al., 2012). Pada penelitian ini daya lekat belum
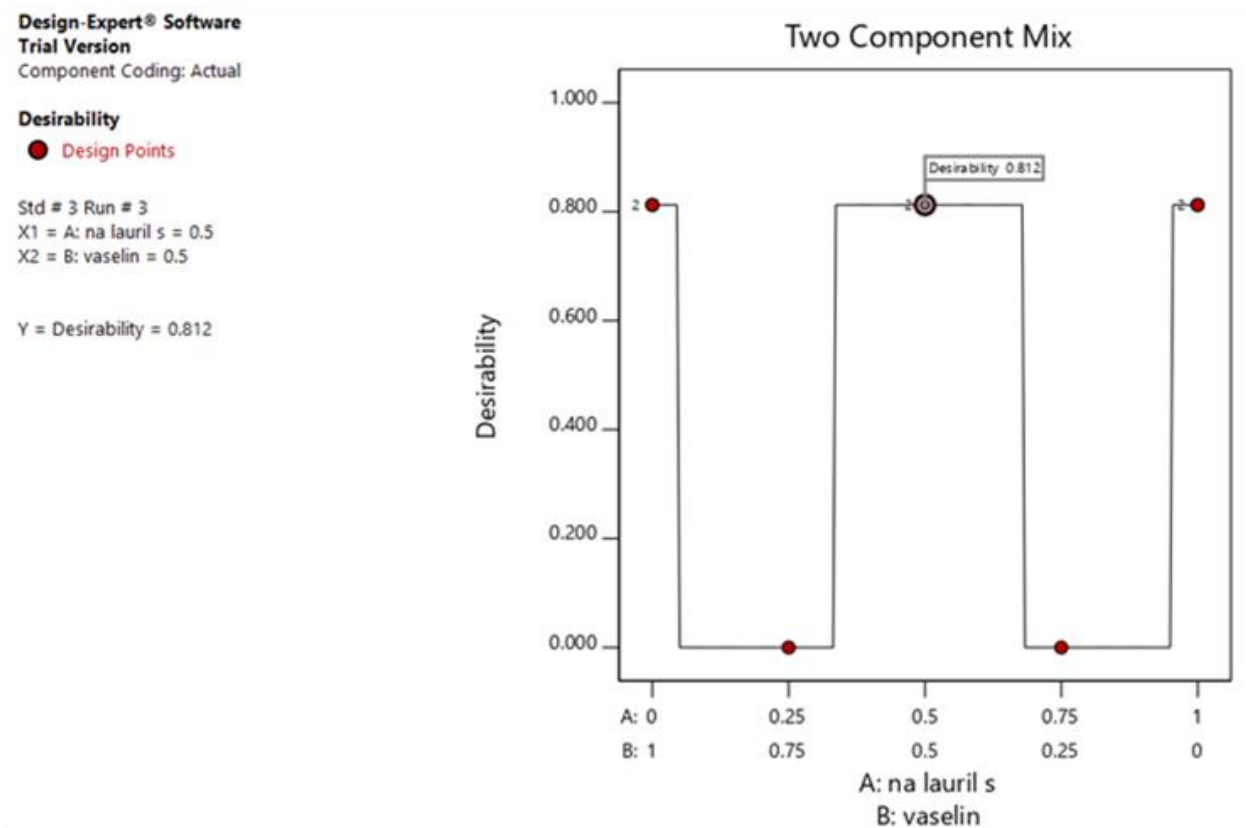

Gambar 2. Nilai desirability 
ad-Dawaa'J.Pharm.Sci. Vol. 2 No. 1, Juni 2019

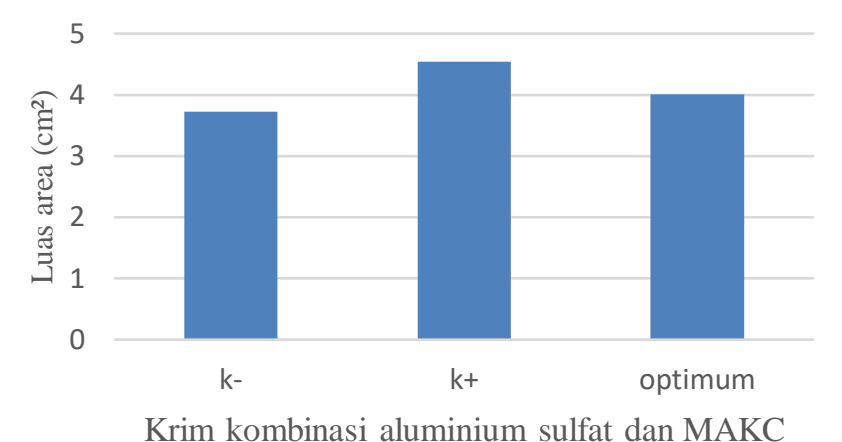

Gambar 3 . Diagram daya sebar krim kombinasi aluminium sulfat dan MAKC

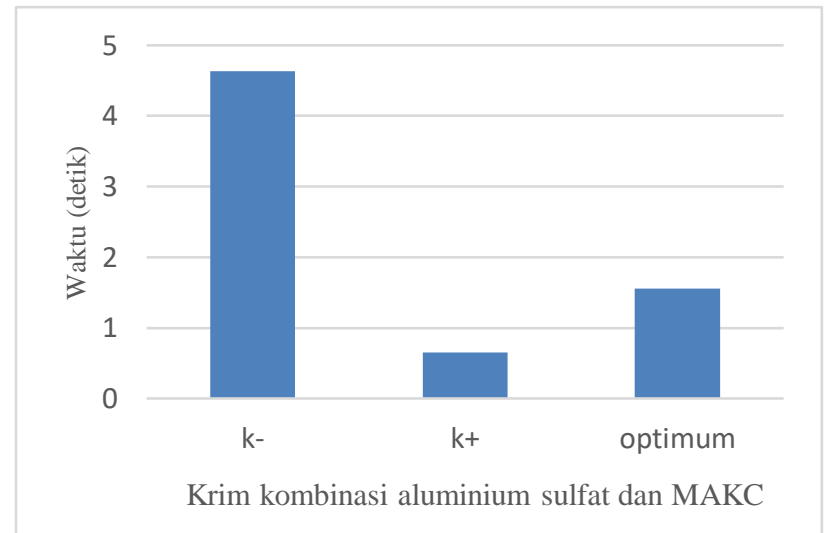

Gambar 4. Diagram daya lekat krim kombinasi aluminium sulfat dan MAKC

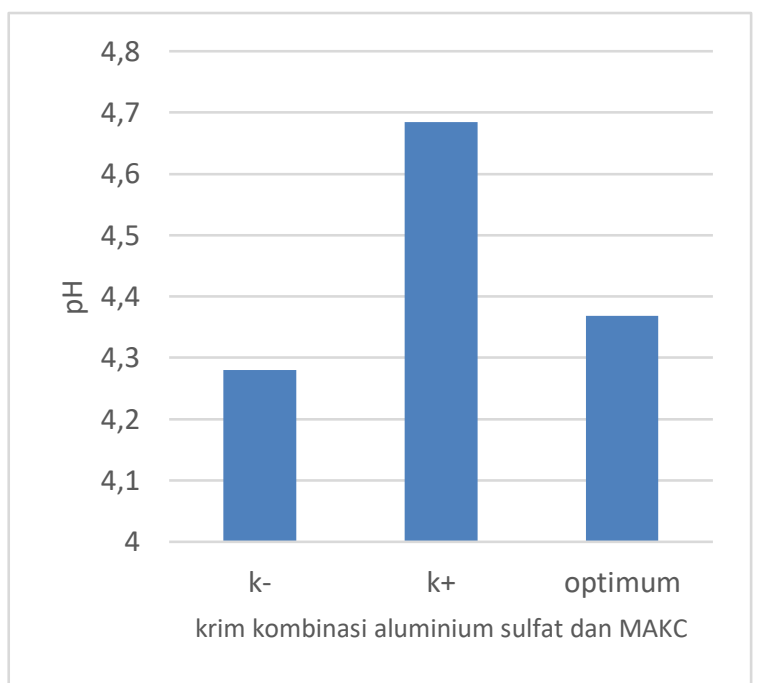

Gambar 5. Diagram pH krim kombinasi aluminium sulfat dan MAKC

memenuhi dari ketentuan yang ada. Nilai berarti ada perbedaan yang bermakna dengan daya lekat formula optimum 1,558 detik. kontrol positif.

Pada pengujian statistik data tidak Untuk pengujian $\mathrm{pH}$ sediaan kulit terdistribusi normal dan homogen dengan uji hendaknya dipilih sediaan yang memiliki pH dengan uji Mann whitney $\mathrm{p}=0,008, \mathrm{p}<0,5$ yang kurang lebih mirip dengan $\mathrm{pH}$ kulit sehingga tidak mudah mengiritasi kulit. Yaitu 
Tabel 4. Hasil Perhitungan Indeks Iritasi

\begin{tabular}{lc}
\hline Kelompok Uji & Indeks Iritasi \\
\hline Tanpa Pemberian & 0 \\
Minyak atsiri & 0 \\
Basis & 0 \\
Formula optimum & 0 \\
\hline
\end{tabular}

antara 4,5-6,5 (Tranggono \& Latifah, 2007). Nilai $\mathrm{pH}$ formula optimumnya yaitu 4.4. Hasil uji di tunjukkan pada gambar 4. Pada penelitian ini $\mathrm{pH}$ memenuhi $\mathrm{pH}$ normal kulit. Pada pengujian statistik data tidak terdistribusi normal dan homogen dengan uji dengan uji Mann whitney $\mathrm{p}=0,008, \mathrm{p}<0,5$ berarti ada perbedaan yang bermakna dengan kontrol positif.
Untuk pengujian viskositas sediaan topikal 2000-50000 Cp (SNI, 1996). Nilai viskositas formula optimumnya yaitu 28285,2 Cp. Pada penelitian ini viskositas memenuhi persyaratan. Pada pengujian statistik data terdistribusi normal dan homogen dengan uji dengan anova $\mathrm{p}=0,593, \mathrm{p}>0,5$ berarti tidak ada perbedaan yang bermakna dengan kontrol positif. Profil viskositas krim ditunjukkan pada gambar 6 .

Hasil uji iritasi seperti yang disajikan pada tabel 4. Dapat dilihat dari hasil bahwa sediaan Krim tidak menimbulkan iritasi.

Hasil aseptabilitas diperoleh skor sebesar

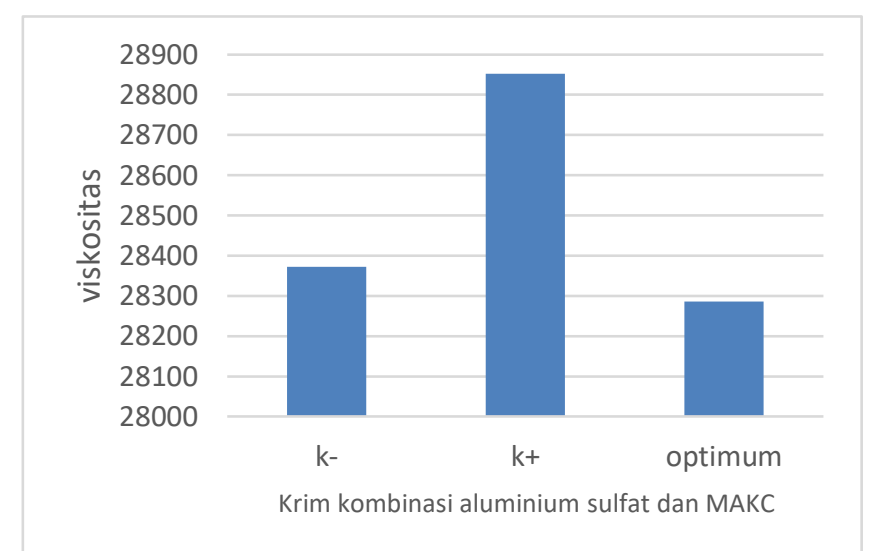

Gambar 6. Diagram pH krim kombinasi aluminium sulfat dan MAKC

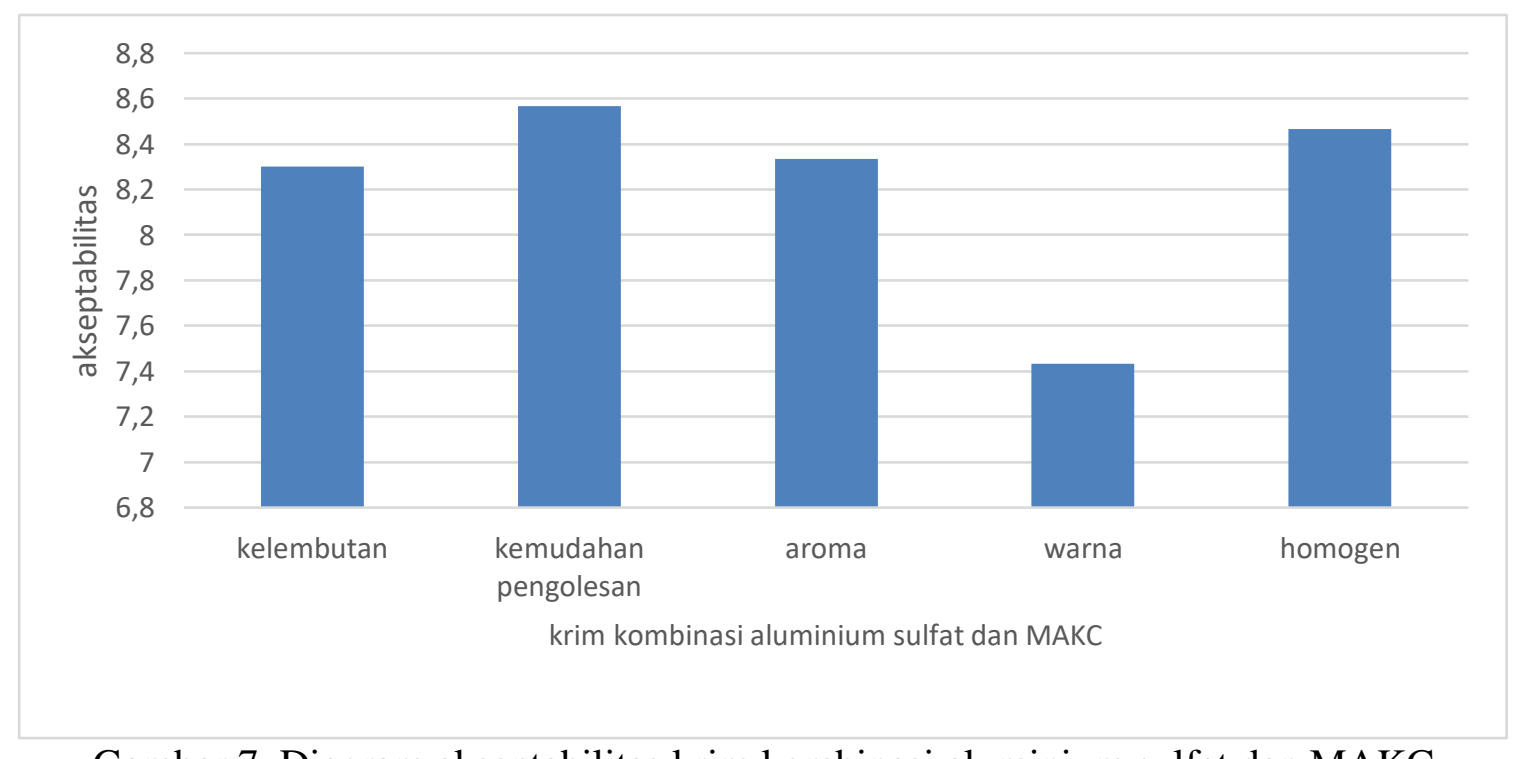

Gambar 7. Diagram akseptabilitas krim kombinasi aluminium sulfat dan MAKC 
8,3 untuk kelembutan ketika dioleskan, skor 8,6 untuk kemudahan saat pengolesan, skor 8.3 untuk aroma sediaan yang dihasilkan, skor 7.4 untuk warna sediaan, dan skor 8.4 untuk homogenitas dari krim deodorant kombinasi alumunium sulfat dan minyak cendana.

\section{TERIMAKASIH}

Penelitian ini terlaksana atas dana internal Unissula tahun anggaran 2017/2018.

\section{KESIMPULAN}

Kesimpulan dari penelitian ini yaitu formula optimum krim deodoran yang dibuat dari kombinasi aluminium sulfat dan minyak atsiri kayu cendana memiliki daya lekat 1.558 detik, daya sebar $4.01 \mathrm{~cm}$, pH 4,4 dan nilai viskositasnya adalah 28285,2 cP. Krim tersebut tidak menimbulkan iritasi dan memberikan kenyamanan saat digunakan.

\section{DAFTAR PUSTAKA}

Astuti, I. Y., Hartanti, D., \& Aminiati, A. (2010). Peningkatan Aktivitas Atijamur Candida ALbicans Salep Minyak Atsiri Daun Sirih (Piper bettle Linn.) Melalui Pembentukan Kompleks Inklusi Dengan Beta-siklodekstrin. Majalah Obat Tradisional, 15, 94-99.

Billany, M. R. (2002). Emulsion in Aulton M.E., Pharmaceutics: The Science of Dosage Form Design. England: Churchill Livingstone.

Butler, H. (2000). Poucher's Perfumes, Cosmetics and Soaps (10 ed.). Britain: Kluwer Academic Publishers.

Djuanda, A. (2008). Dermatitis Seboroik, Ilmu Penyakit Kulit dan Kelamin, Fakultas Kedokteran Universitas Indonesia (5 ed.). Jakarta: Balai Penerbit FK UI.

Fatmawaty, A., Manggau, M. A., Tayeb, R., \& Adawiah, R. (2016). Uji Iritasi Krim
Hasil Fermentasi Bunga Rosella (Hibiscus sabdariffa L.) dengan Variasi Konsentrasi Emulgator Novemer Pada Kulit Kelinci (Oryctalagus cuniculus). Journal of Pharmaceutical and Medicinal Sciences, 1(2), 62-65.

Garg, A. D., Aggarwal, S. G., \& Sigla, A. K. (2002). Spreading of Semisolid Formulation: An Update.

Irsan, M. A., Manggav, E., Pakki, \& Usmar. (2013). Uji Iritasi Krim Antioksidan Ekstrak Biji Lengkeng (Euphoria Longana Stend) Pada Kulit Kelinci (Oryctolagus Cuniculus). Majalah Farmasi dan Farmakologi, 2(17), 55-60.

Naibaho, D. H., Yamkan, V. Y., Weni, \& Wiyono. (2013). Pengaruh Basis Salep Terhadap Formulasi Sediaan Salep Ekstrak Daun Kemangi (Ocinum sanchum L.) Pada Kulit Punggung Kelinci yang Dibuat Infeksi Staphylococcus Aureus. Jurnal Ilmiah Farmasi UNSRAT, II(2).

POM, D. (1985). Formularium Kosmetika Indonesia. Jakarta: Departemen Kesehatan RI.

Rahayu, S., Sherley, \& Indrawati, S. (2009). Deodorant-antiperspirant. Jakarta: Naturakos IV BPOM RI.

Rahmawati, D., Sukmawati, A., \& Indrayudha, P. (2010). Formulasi Krim Minyak Atsiri Rimpang Temu Giring (Curcuma heyneana): Uji Sifat Fisik dan Daya Antijamur Terhadap Candida Albicans Secara In Vitro. Majalah Obat Tradisional, 2(15), 56-63.

Ramadhani, R. A., Riyadi, H. S., Triwibowo, B., \& Kusumaningtyas, R. D. (2017). Review Pemanfaatan Design Expert Untuk Optimasi Komposisi Campuran Minyak Nabati Sebagai Bahan Baku Sintesis Biodiesel . J. Tek. Kim. Ling, I(1), 11-16.

Saryanti, D., \& Izzatun, N. Z. (2017). Optimasi Karbopol dan Gliserol Sebagai Basis Gel Antiseptik Tangan Ekstrak Etanol Daun Ceremai (phyllantus acidus L.) dengan Metode SimplexLattice Design. Journal of Pharmaceutical Sciencce and Clinical Research(2), 35-43.

Tranggono, R. I., \& Latifah, F. (2007). Buku Pegangan Ilmu Pengetahuan Kosmetik. Jakarta: Gramedia Pustaka Utama. 
Ulaen, Selfie, P. J., Banne, Yos Suatan, \& Ririn , A. (2012). Pembuatan Salep Antijerawat dari Ekstrak Rimpang Temulawak (Curcuma xanthorrhiza Roxb.). Jurnal Ilmiah Farmasi, 3(2), 4549.

Wen, H. W. (2009). Ablation of Apocrine Glands With The Use Of Suction-assisted Cartilage Shaver For Treatment Of Axillary Bromhidrosis. Archive of Dermatological Research, 272, 321-329.

Widodo, H. (2013). Ilmu Meracik Obat Untuk Apoteker (1 ed.). Jogjakarta: D-Medika. 